Article

\title{
The Microbial Communities of Leaves and Roots Associated with Turtle Grass (Thalassia testudinum) and Manatee Grass (Syringodium filliforme) are Distinct from Seawater and Sediment Communities, but Are Similar between Species and Sampling Sites
}

\author{
Kelly Ugarelli, Peeter Laas and Ulrich Stingl * \\ Ft. Lauderdale Research and Education Center, Department of Microbiology and Cell Science, UF/IFAS, \\ University of Florida, Davie, FL 33314, USA; kugarelli@ufl.edu (K.U.); peeter.laas@ufl.edu (P.L.) \\ * Correspondence: ustingl@ufl.edu; Tel.: +1-954-577-6326
}

Received: 4 December 2018; Accepted: 22 December 2018; Published: 26 December 2018

\begin{abstract}
Seagrasses are vital members of coastal systems, which provide several important ecosystem services such as improvement of water quality, shoreline protection, and serving as shelter, food, and nursery to many species, including economically important fish. They also act as a major carbon sink and supply copious amounts of oxygen to the ocean. A decline in seagrasses has been observed worldwide, partly due to climate change, direct and indirect human activities, diseases, and increased sulfide concentrations in the coastal porewaters. Several studies have shown a symbiotic relationship between seagrasses and their microbiome. For instance, the sulfur, nitrogen, and carbon cycles are important biochemical pathways that seem to be linked between the plant and its microbiome. The microbiome presumably also plays a key role in the health of the plant, for example in oxidizing phyto-toxic sulfide into non-toxic sulfate, or by providing protection for seagrasses from pathogens. Two of the most abundant seagrasses in Florida include Thalassia testudinum (turtle grass) and Syringodium filliforme (manatee grass), yet there is little data on the composition of the microbiome of these two genera. In this study, the microbial composition of the phyllosphere and rhizosphere of Thalassia testudinum and Syringodium filiforme were compared to water and sediment controls using amplicon sequencing of the V4 region of the 16S rRNA gene. The microbial composition of the leaves, roots, seawater, and sediment differ from one another, but are similar between the two species of seagrasses.
\end{abstract}

Keywords: seagrass; phyllosphere; rhizosphere; microbiome

\section{Introduction}

Seagrasses are found nearly worldwide, excluding Antarctica [1,2], and the total area of seagrass coverage has been estimated between 300,000 to $600,000 \mathrm{~km}^{2}$ [3,4]. Seagrasses provide many essential ecological benefits, such as storage of blue carbon, supplying food, shelter, nursery, and ecosystem engineering (reviewed by Ugarelli et al. 2017 [5]). Not only are seagrasses a major carbon sink [6], but also, as a byproduct of photosynthesis, one square meter of seagrass-meadow can emit up to $10 \mathrm{~L}$ of oxygen daily [7]. Seagrasses, along with mangroves and coral reefs, also help buffer harsh waves and prevent the stir-up of sediment $[8,9]$. Their roots extend vertically and horizontally, and the rhizomes extend horizontally, which allows them to withstand the forces of strong tides [8] and prevent uprooting, even with heavily grazed canopies [9]. Seagrass beds also significantly reduce the number of pathogens present in the water column [10]. 
Many species of fauna depend on seagrasses for food and nutrition. For example, manatees can eat between 30 to $55 \mathrm{~kg}$ of seagrass daily [11,12], and sea turtles can eat about $2 \mathrm{~kg}$ of seagrass per day [7]. Crustaceans and snails will also occasionally consume seagrass leaves $[7,13,14]$. Other species that take advantage of seagrasses for food include carnivores who feed on the animals that are frequently found living within the seagrass meadows [13-16]. Decaying seagrasses serve as food for other organisms such as worms, sea cucumbers, crabs and filter feeders, as well as fauna both near shore and in the deeper ocean where dead seagrass and debris are carried by waves [7]. Decomposition of the seagrasses eventually leads to the release of nutrients, including nitrogen and phosphorous, which can then be reabsorbed by live seagrasses and phytoplankton [13].

Losses in the seagrass population have been observed throughout the world. Waycott et al. 2009 [17] estimated that about a third of the area covered by seagrasses has disappeared since 1879 , and so have the ecosystem services provided by them. Siltation [18-20], damming and waste disposal [14,21,22], as well as climate change [23], have caused major impacts on seagrass beds. Increases in nutrient concentrations, namely nitrogen and phosphorous [24], due to effluence of fertilizers lead to extensive growth of epiphytes and pelagic algae in the water that block sunlight from reaching seagrass leaves [24-29]. Sulfide, a highly toxic compound for animals and plants, is extremely detrimental to seagrasses worldwide $[30,31]$. Toxic sulfide can be taken up into the shoots because of low oxygen levels in the sediment [32,33]. Normally, seagrasses can detoxify low levels of sulfide by oxygenating their roots [34,35] and through incorporating sulfur into their biomass as thiols [36], but higher concentrations are toxic.

Symbiotic microbes are important for the fitness, growth and survival of plants [37]. Important biochemical processes linked between the host and symbionts include reactions in the carbon, nitrogen, and sulfur cycles. Dissolved organic carbon (DOC) that is exuded from the roots and leaves of the seagrasses can serve as the main carbon source for bacteria associated with seagrasses [38-41], which includes bacteria that can provide nitrogen to the plant host [42-46]. Biochemical processes in the nitrogen cycle, e.g., nitrification, denitrification and ammonification, occur at higher rates in the rhizosphere of seagrasses than in bare sediments, likely due to microbial activity $[42,47,48]$. Nitrogen-fixing prokaryotes found both in the phyllosphere [49] and the rhizosphere can provide between $30 \%$ and $100 \%$ of the nitrogen requirement of seagrasses [42-46]. Sulfate-reduction is higher in the rhizosphere sediment than in non-vegetated sediments [50-52]. Even though they prefer anoxic conditions, root surface-associated sulfate reducers seem to have a high tolerance for oxygen [53]. Recently, also sulfur-oxidizing cable bacteria have been reported to be part of the seagrass rhizosphere [54].

The recent and on-going decrease in seagrass beds calls for further research on different aspects of these plants. Microbial community composition, such as the composition of the human gut microbiome, are generally useful bio-indicators for changes that may cause stress on the host. Rather than only relying on the physiological conditions of the plants, analysis of healthy plants and their microbiomes will determine a core-microbiome that can be used as a bio-indicator. Several studies that have explored the microbiome of seagrasses have focused mainly on the genus Zostera, but few studies have analyzed the microbial communities associated with T. testudinum and even fewer those of S. filiforme (reviewed in Ugarelli et al. 2017 [5]) despite their importance and their value to marine animals [55-58]. In this study, we identified the microbial community composition of different plant sample-types (phyllosphere and rhizosphere) in comparison to seawater and sediment controls of the seagrass species, T. testudinum and S. filiforme.

\section{Materials and Methods}

Samples of T. testudinum and S. filiforme were collected on 14 November 2017, from three sites, Hobie 1, Hobie 2 and Hobie 3, about 0.1 to $1 \mathrm{~km}$ apart off the shore of Hobie Island Beach Park near Key Biscayne, Florida, USA (Figure 1). The physico-chemical properties of the seawater at each sampling site were relatively similar (Table 1). Using a spade, about one $0.09 \mathrm{~m}^{2}$ portion of the seagrass bed 
including its sediment was carved out and placed in a bucket. Sediment samples were scooped from the collected seagrass carvings with a $50 \mathrm{~mL}$ conical tube, about $5 \mathrm{~cm}$ in depth. The remaining seagrass was placed in a $19 \mathrm{~L}$ ziplock bag. We collected one $0.09 \mathrm{~m}^{2}$ sample of each species per site and one sample of sediment from each seagrass carving. Sediment controls were collected from unvegetated areas about $2 \mathrm{~m}$ away from the seagrass bed with $50 \mathrm{~mL}$ conical tubes pressed down into the sediment, taking cores of about $5 \mathrm{~cm}$. Using sterile $5 \mathrm{~L}$ carboys, seawater was collected from above the seagrass meadows at each site. Due to the proximity of both seagrass species throughout the vegetation, only one sample of water was taken from each site. All seagrass and sediment samples were placed on ice for transfer to the lab. All samples were stored at $4{ }^{\circ} \mathrm{C}$ until processing the next day. We refer to leaves, roots, rhizomes, seawater, and sediments as sample-types.

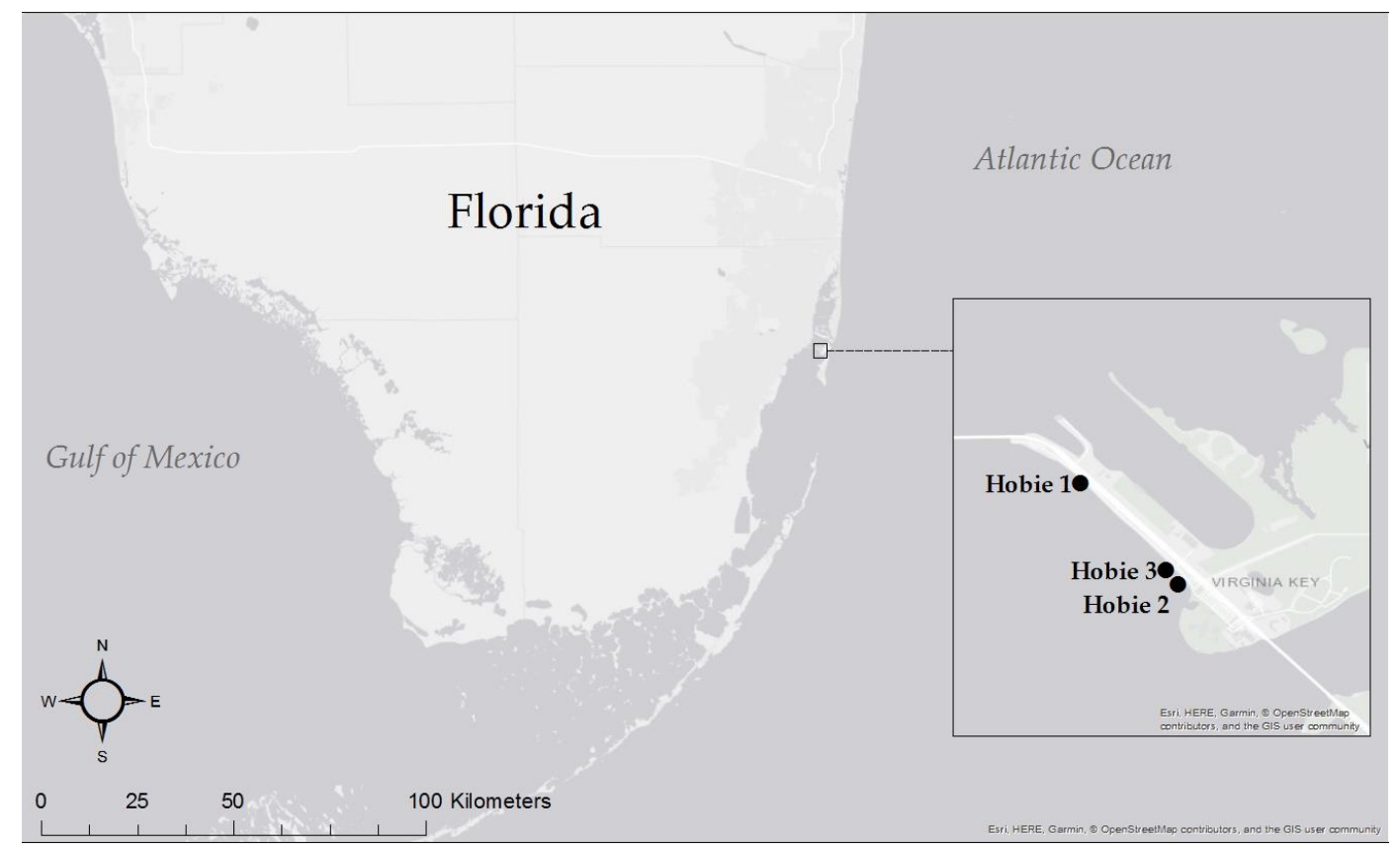

Figure 1. Map of the study area showing sampling locations, Hobie 1 (H1), Hobie 2 (H2), Hobie 3 (H3).

Table 1. Location of sampling sites and physico-chemical parameters of the seawater at each location.

\begin{tabular}{ccccccc}
\hline Site & Latitude & Longitude & $\mathbf{p H}$ & Temperature $\left({ }^{\circ} \mathbf{C}\right)$ & Salinity $(\mathbf{p p t})$ & Conductivity $(\mu \mathrm{S} / \mathrm{cm})$ \\
\hline Hobie 1 & 25.743298 & -80.173982 & 8.05 & 28.7 & 9.79 & 19.55 \\
Hobie 2 & 25.736188 & -80.167161 & 8.28 & 30.4 & 9.48 & 18.95 \\
Hobie 3 & 25.737209 & -80.167979 & 8.2 & 31 & 9.36 & 18.72 \\
\hline
\end{tabular}

To process the seagrass samples, protocols from Weidner et al. 1996 [59] and White et al. 2015 [60] were adapted, where the microbial community associated with the plants are removed in a series of sonications. Briefly, we gently rinsed the seagrasses with autoclaved seawater to remove loose sediment. The leaves and roots of both species and the rhizome of T. testudinum were then detached using sterile blades. For the phyllosphere, $8 \mathrm{~cm}$ long segments were cut from the center of the leaves. For analyzing 'rhizosphere', the roots were severed from the rhizome and shoots. T. testudinum rhizomes were cut to $8 \mathrm{~cm}$ in length. About 10 cuttings of leaves, 30 cuttings of roots, and one cutting of the rhizome were placed into separate $50 \mathrm{~mL}$ conical tubes containing $30 \mathrm{~mL}$ of sterile seawater until the tubes were lightly packed. The tubes were then positioned in a styrofoam raft and placed in a sonication bath filled with deionized water. The samples were sonicated for $12 \mathrm{~s}$ using the ME 4.6 ultrasonic cleaner (Mettler Electronics, Anaheim, CA, USA). Using sterile forceps, the samples were transferred to a new conical tube containing $30 \mathrm{~mL}$ of seawater and sonicated a second time for $12 \mathrm{~s}$. 
The third and final sonication ran for $1 \mathrm{~min}$. Because of the smaller rhizome biomass of S. filiforme when compared to T. testudinum, S. filiforme rhizomes were excluded from this study.

The leaves, roots and rhizomes were removed using sterile forceps, and the supernatant was pre-filtered through $100 \mu \mathrm{m}$ nylon mesh filters (Fisher Scientific, Pittsburgh, PA, USA) to remove the excess plant material. Thereafter, the supernatant was vacuum-filtered through a $5 \mu \mathrm{m}$ nitrocellulose (MF-Millipore, Darmstadt, Germany) membrane to remove the remaining debris. The bacterial cells were then filtered onto a $0.22 \mu \mathrm{m}$ nitrocellulose membrane (MF-Millipore, Darmstadt, Germany). Two liters of each seawater sample were also vacuum-filtered through 5 and $0.22 \mu \mathrm{m}$ filters. All $0.22 \mu \mathrm{m}$ filters were processed following the manufacturer's recommended protocol for the Qiagen PowerWater Kit for DNA extractions. DNA from $0.3 \mathrm{~g}$ of sediment from the surface of the each conical tube was extracted using the Qiagen PowerSoil kit for DNA extraction. All DNA extracts were kept at $-20{ }^{\circ} \mathrm{C}$ until preparation for sequencing.

DNA sequence data was generated using Illumina paired-end sequencing $(151 \mathrm{bp} \times 12 \mathrm{bp} \times$ $151 \mathrm{bp}$ MiSeq run) at the Environmental Sample Preparation and Sequencing Facility at Argonne National Laboratory (Chicago, IL, USA). DNA extracts were used as templates for the amplification of the V4 hypervariable region of the 16S rRNA gene [61]. The primer pair used was 515F-806R, which contained adapter sequences as well as a twelve-base barcode sequence for multiplexing in the reverse amplification primer. Each $25 \mu \mathrm{L}$ PCR reaction contained $9.5 \mu \mathrm{L}$ of MO BIO PCR Water (Qiagen, Germantown, MD, USA), $12.5 \mu \mathrm{L}$ of QuantaBio's AccuStart II PCR ToughMix (Quantabio, Beverly, MA, USA; $2 \times$ concentration, $1 \times$ final $), 1 \mu \mathrm{L}$ Forward Primer $(5 \mu \mathrm{M}$ concentration, $200 \mathrm{pM}$ final), $1 \mu \mathrm{L}$ Golay barcode tagged Reverse Primer ( $5 \mu \mathrm{M}$ concentration, $200 \mathrm{pM}$ final), and $1 \mu \mathrm{L}$ of template DNA. The conditions for PCR were as follows: $94{ }^{\circ} \mathrm{C}$ for 3 min to denature the DNA, with 35 cycles at $94{ }^{\circ} \mathrm{C}$ for $45 \mathrm{~s}, 50{ }^{\circ} \mathrm{C}$ for $60 \mathrm{~s}$, and $72{ }^{\circ} \mathrm{C}$ for $90 \mathrm{~s}$, and a final extension of $10 \mathrm{~min}$ at $72{ }^{\circ} \mathrm{C}$ to ensure complete amplification. Amplicons were then quantified using PicoGreen (Invitrogen, Eugene, OR, USA) and a plate reader (Infinite ${ }^{\circledR} 200$ PRO, Tecan, Männedorf, Switzerland). Once quantified, volumes of each of the products were pooled into a single tube to represent each amplicon in equimolar amounts. This pool was then cleaned up using AMPure XP Beads (Beckman Coulter, Indianapolis, IN, USA), and then quantified using a fluorometer (Qubit, Invitrogen, Eugene, OR, USA). After quantification, the molarity of the pool was determined and diluted down to $2 \mathrm{nM}$, denatured, and then diluted to a final concentration of $6.75 \mathrm{pM}$ with a $10 \%$ PhiX spike for sequencing on an Illumina MiSeq. The raw data has been submitted to the BioProject database and is available at: http://www.ncbi.nlm.nih.gov/bioproject/511001.

The QIIME 2 microbiome analysis package [62], the successor to QIIME [63], was used for sequence analysis. Therein, quality filtering, chimera identification and merging of paired-end reads was carried out with the DADA2 plugin [64]. SILVA release 132 (Ref NR 99) taxonomy [65] and q2-feature-classifier [66] were used for classification of the 16S rRNA gene sequences. Data filtering and statistical analysis were completed through $R$ version 3.2.0 [67]. Sequence variants (SVs) classified as chloroplasts or mitochondria were discarded from the dataset. Several additional $\mathrm{R}$ packages were used for data analysis and visualization: SeqinR [68], clusterSim [69], reshape2 [70], ggplot2 [71], VennDiagram [72], and vegan [73]. Analyses of predictive metagenomes were done with the MicrobiomeAnalyst Shotgun Data Profiling (SDP) module [74], which determines functional diversity profiles of the KEGG Orthology (KO)-annotated genes. ArcMap ${ }^{\mathrm{TM}}$ from the $\operatorname{ArcGIS}^{\circledR}$ software $^{\circ}$ by Esri (Redlands, CA, USA), version 10.5.1 [75] was used to make the map in Figure 1.

\section{Results}

A total number of $2,128,087$ sequences that comprised 17,686 sequence variants (SVs) were generated in this study (Table 2). The number of SVs in the turtle grass rhizosphere was 3373, 2771 SVs were recovered from the manatee grass rhizosphere, and $3597 \mathrm{SVs}$ were present attached to the turtle grass rhizome. The turtle grass phyllosphere had 3347 SVs and the manatee grass phyllosphere had 
4062 SVs. Both of the seagrass sediments contained 4033 SVs, and the sediment control had 4650 SVs. The water samples contained the least amount of SVs with only 757.

Table 2. Total number of Sequence Variants (SV) per seagrass-associated habitats. Three replicates per sample. (T: turtle grass; M: manatee grass; C: control).

\begin{tabular}{cc}
\hline Sample Type & Number of SV \\
\hline Roots T & 3373 \\
Roots M & 2771 \\
Leaves T & 3347 \\
Leaves M & 4062 \\
Rhizome T & 3597 \\
Sediment C & 4650 \\
Sediment T & 4033 \\
Sediment M & 4033 \\
Seawater & 757 \\
All samples & 17686 \\
\hline
\end{tabular}

\subsection{Alpha Diversity}

After normalization, the alpha diversity of the bacterial communities was generally higher in the phyllosphere, rhizosphere and sediment than in the seawater samples (Figures S1 and S2, Tables S1 and S2). The phyllosphere and the sediment control communities have the highest species richness, followed by the rhizomes. The root and seagrass sediment communities showed similar alpha diversities. The sampling depth covered most of the diversity within the samples, as the rarefaction curves of most samples plateaued between 1000 to 2000 sequences. The highest diversity was found in the manatee grass leaves from Hobie 2 (Figure S2).

\subsection{Beta Diversity}

The community compositions of the different sample-types were clearly distinct (Figure 2): The root and rhizome communities clustered more closely together and were more similar to the sediments than to the water samples. The phyllosphere samples grouped separately from the water and the belowground samples, and the water samples were the most distinct group and clustered separately from all other samples.

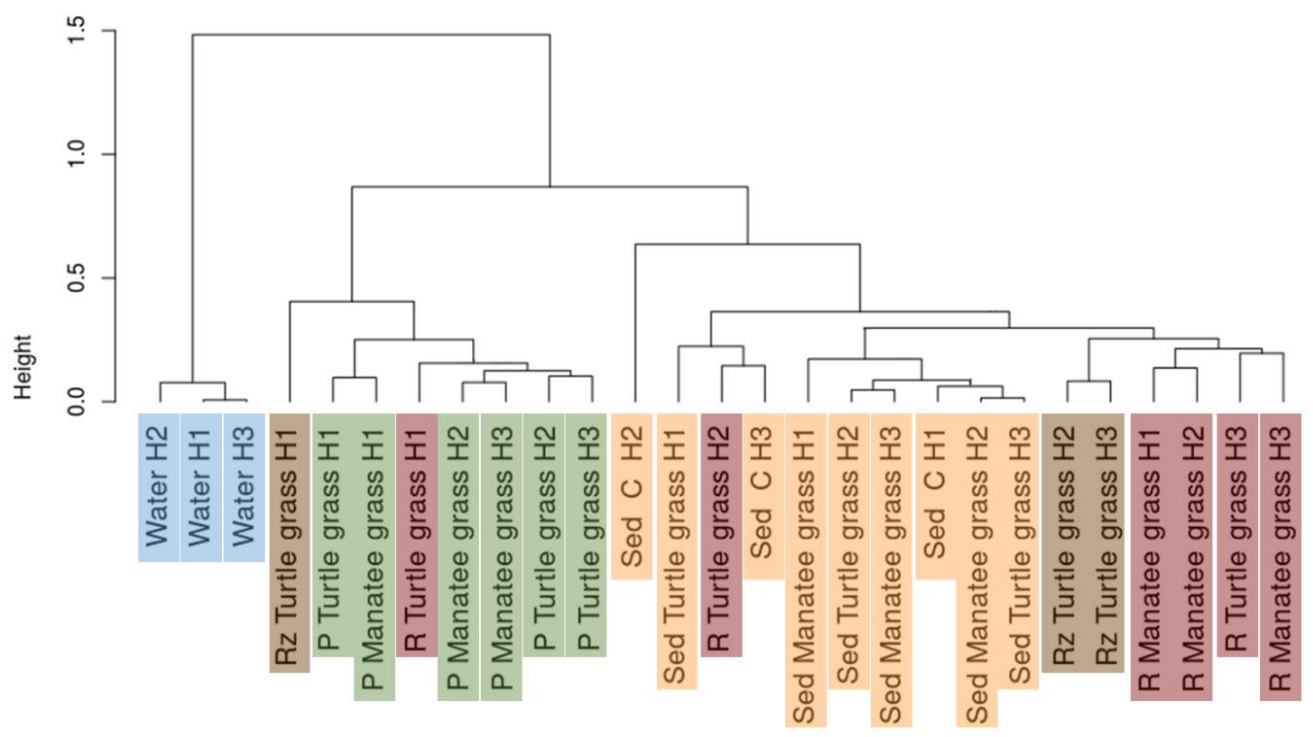

Figure 2. Dendrogram of the weighted Unifrac distance matrix of the microbial communities in each sample of water, sediment, phyllosphere and rhizosphere of both manatee grass and turtle grass, and the rhizomes of turtle grass. (H1: Hobie 1; H2: Hobie 2; H3: Hobie 3; P: phyllosphere; R: rhizosphere; Rz: rhizome; C: control; Sed: sediment). Colors indicate different sample-types. 


\subsection{Sequence Variants and Abundant Genera}

Due to the large quantities of unique SVs in each sample, only the most abundant SVs that comprised more than $0.01 \%$ of the total SVs were considered in order to compare the main members of the microbiome and to exclude rare taxa (or potential sequencing errors) (Figure 3a). Almost half (49\%) of the abundant SVs were shared among seagrass-associated sample-types-phyllosphere, sediment, and rhizosphere (Figure $3 \mathrm{~b}$ ). Only about $1.2 \%$ of the abundant SVs were common to all the samples including the water.

(a)

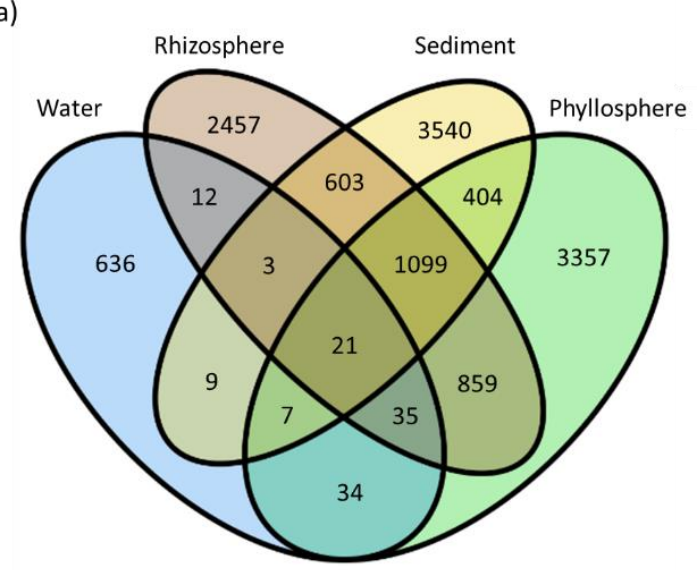

(b)

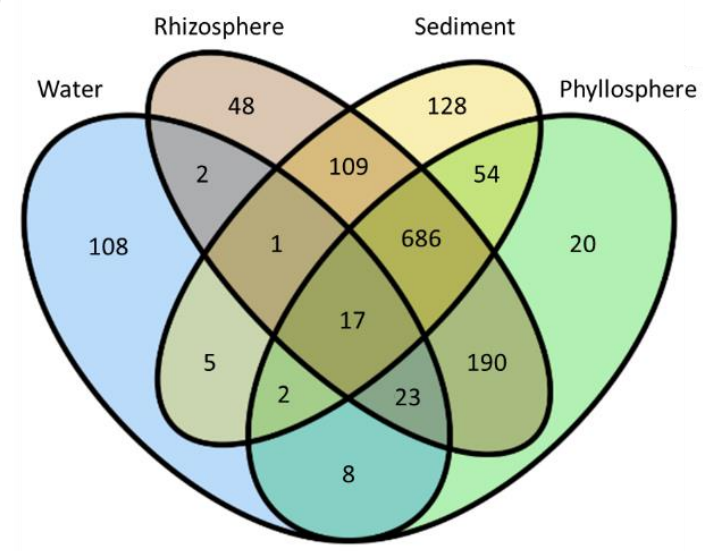

Figure 3. Venn diagrams comparing the number of sequence variants (SVs) shared among the water, rhizosphere, phyllosphere, and seagrass sediments (a) Complete set of SVs, (b) SVs that make up more than $0.01 \%$ of the total SVs.

\subsubsection{Aboveground}

Aboveground samples showed a clear difference between the leaf communities of both species and their surrounding seawater (Figure 4a): Phyllospheres of both seagrass species were more similar to each other than they were to the seawater, with $56 \%$ of all the SVs found only on the seagrass leaves of both species. Of all the SVs, $3 \%$ were common to both phyllospheres and seawater together, and less than $1 \%$ of the SVs were shared between the phyllosphere of either seagrass species and the seawater.

The most abundant genera common to both leaves and seawater were Alphaproteobacteria, Rhodobacteraceae, and Alteromonadales (Figure 5). Crymorphaceae, Flavobacteriaceae, Pelagibacteraceae, Chromatiales, Oceanospirillales, and Candidatus Portiera were abundant mainly in seawater. Piscirickettsiaceae, Myxococcales, Desulfobulbaceae, Desulfococcus, Saprospiraceae, and Flammeovirgaceae were abundant mainly in the phyllospheres. 
(a)

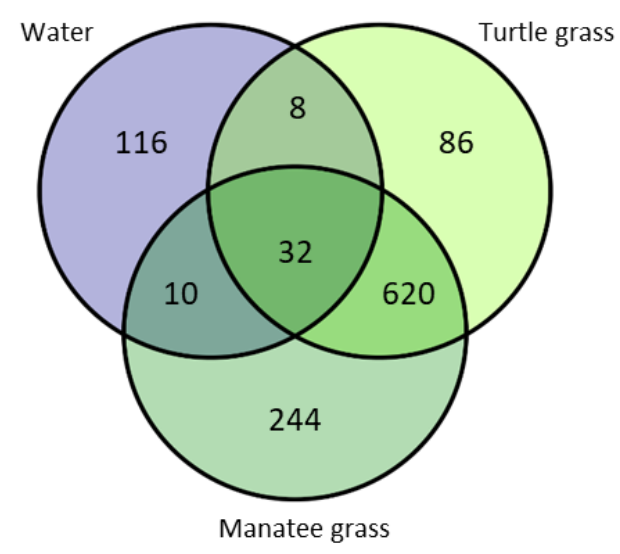

(b)

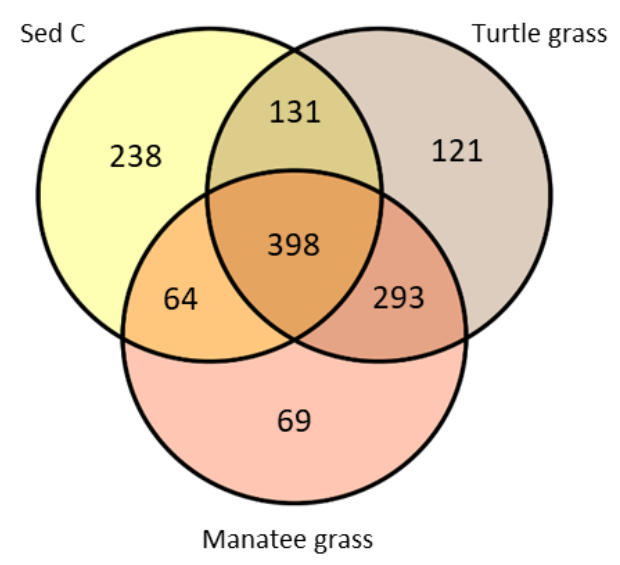

(c)

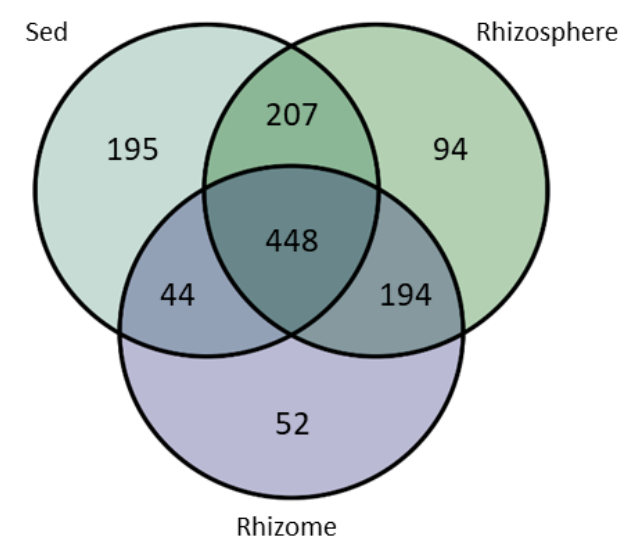

(d)

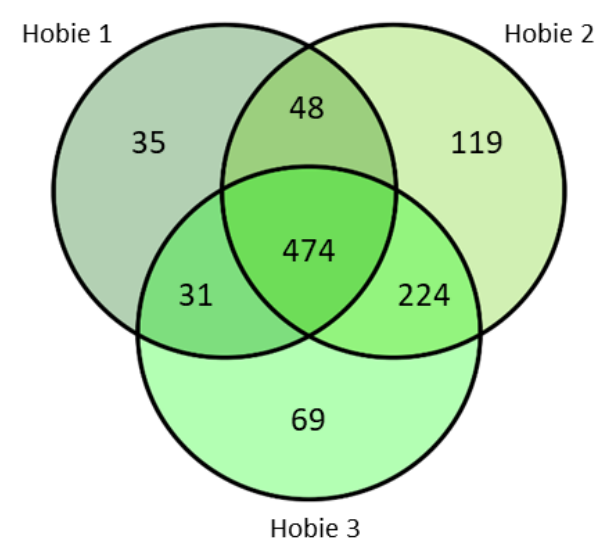

(e)

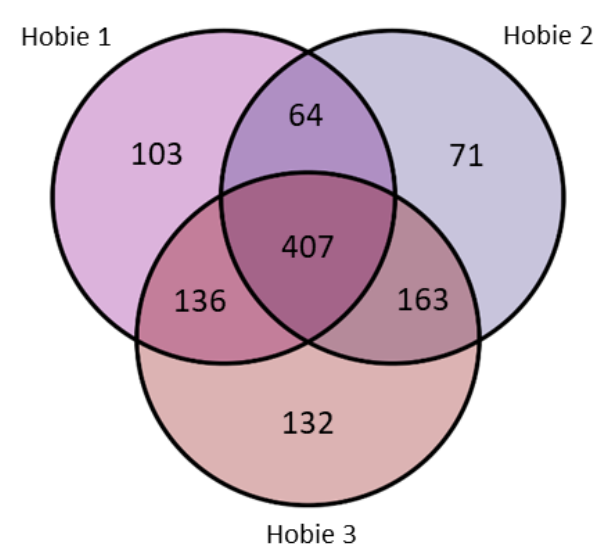

Figure 4. Venn diagrams comparing the most common SVs that comprise more than $0.01 \%$ of the total SVs unique to or shared among (a) all the phyllosphere and water samples, (b) all the rhizosphere and sediment control samples, (c) the sediment, rhizospheres, and rhizomes of turtle grass, (d) all the phyllospheres of the sample sites, and (e) all the rhizosphere of the sample sites. (Sed: sediment; C: control). 


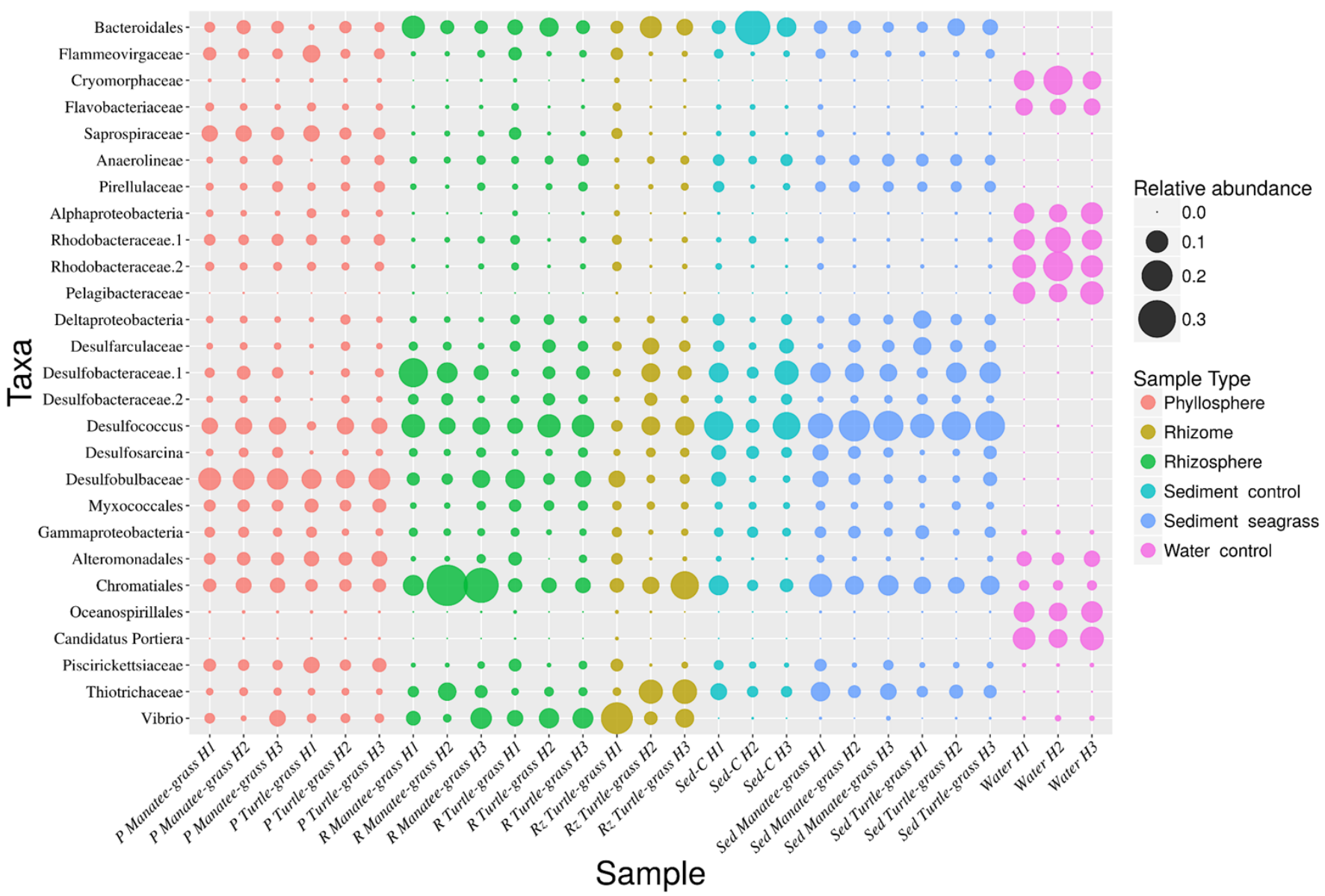

Figure 5. Relative abundance of the taxa comprising more than $1 \%$ of the bacterial sequences in each sample. Taxa are classified to the lowest rank possible according the classifier. (H1: Hobie 1; H2: Hobie 2; H3: Hobie 3; P: phyllosphere; R: rhizosphere; Rz: rhizome; C: control; Sed: sediment).

\subsubsection{Belowground}

Unlike the aboveground sample-type communities, the belowground communities showed similarity among each other and the surrounding sediments (Figure $4 \mathrm{~b}$ ). The rhizospheres of both species are more similar to each other than to the sediments controls, with $22 \%$ of the SVs found only in the two rhizospheres, while they shared less than $10 \%$ of the SVs each with the sediment controls. However, $30 \%$ of the SVs were present on the roots of both species and the sediment controls.

The turtle grass rhizome and root communities were compared to the turtle grass sediments (Figure 4c). The number of SVs common to only the roots and the sediment was 17\%, and the number of SVs common to only the roots and the rhizome was $16 \%$. The rhizome shared $4 \%$ of the SVs with only the sediment. In the rhizomes, roots, and sediments of turtle grass, $36 \%$ of the belowground SVs were present.

The predominant taxa common to all belowground components were Chromatiales, Desulfococcus, Desulfobacteraceae, and Bacteroidales (Figure 5). Gammaproteobacteria, Desulfosarcina, Deltaproteobacteria, Pirellulaceae, Thiotrichaceae, and Anaerolineae were the most prevalent taxa in the sediments while Vibrio and Thiotrichaceae were more abundant in the rhizome and roots.

\subsubsection{Leaves vs. Roots and Rhizomes}

We compared the microbial communities of the leaves and roots of both seagrass species to the turtle grass rhizomes, and found that $47 \%$ of the SVs were common to these three sample-types (Figure S3). $6 \%$ of the SVs were only found on the leaves and $5 \%$ were exclusive to the roots. $1 \%$ of the SVs 
were only found on the rhizomes and phyllospheres, and $8 \%$ of the SVs were only present on the rhizome and roots.

\subsubsection{Turtle Grass Sample-Types}

When comparing the leaves, rhizome, roots, and sediments of T. testudinum, $28 \%$ of the SVs were present in all sample-types (Figure S4g). The turtle grass sediment was more diverse, with over $13 \%$ of all the SVs present only in the turtle grass sediment. $6 \%$ of the most abundant SVs were only recovered from both the phyllosphere and rhizosphere of turtle grass.

\subsubsection{Manatee Grass Sample-Types}

In manatee grass, $38 \%$ of the abundant SVs were shared between the leaves, roots, and manatee grass sediments (Figure S4h). The phyllosphere and the rhizosphere communities were more similar to each other than to the sediment communities, with $19 \%$ of the SVs present only in these two sample-types and not the sediment. Interestingly, the sediment and the phyllosphere alone shared 10\% of the SVs, while the sediment and the roots alone shared $5 \%$. The sediment is more distinct than the other sample-types in manatee grass, with more than $16 \%$ of the SVs present only in the sediment.

\subsubsection{Differences in Genera-Abundance by Seagrass Species}

Several differences between the two seagrass species were observed based on the abundance of the microbes (Figure 5). In the roots of manatee grass, Desulfobacteraceae and Chromatiales were more abundant, while in turtle grass unclassified Deltaproteobacteria and Vibrio were more abundant. The sediments of turtle grass contain more Bacteroidales and unclassified Deltaproteobacteria, whereas the sediments of manatee grass contain more Desulfobacteraceae and Thiotrichaceae. The phyllospheres were mostly uniform; however, Desulfobacteraceae is more prevalent in manatee grass leaves.

\subsubsection{Seawater by Site}

The seawater samples show great resemblance among their microbial communities, with $75 \%$ of the SVs present in all sites (Figure S5). 5\% of the SVs are present only in Hobie 2 and Hobie 3, while $2 \%$ and $3 \%$ are only in Hobie 1 and Hobie 3, and Hobie 1 and Hobie 2, respectively. Hobie 2 seems to be more unique than the other two sites with about $11 \%$ of the abundant SVs exclusively found here.

\subsubsection{Phyllosphere by Site}

The phyllosphere communities of both species in Hobie 2 and Hobie 3 shared 22\% of the SVs. Less than $5 \%$ of the SVs are found only between Hobie 1 and either Hobie 2 or Hobie 3. Nonetheless, $47 \%$ of the SVs were present in all three locations (Figure 4d), suggesting that the leaf communities of all three sites are very similar.

\subsubsection{Rhizosphere by Site}

The rhizospheres of both species in Hobie 1 are more similar to Hobie 3 than Hobie 2, with about $13 \%$ of the SVs present only in Hobie 1 and Hobie 3, and 6\% only between Hobie 1 and Hobie 2 (Figure $4 \mathrm{e}$ ). 15\% of the SVs were exclusively found in Hobie 2 and Hobie 3. The root communities of all three sites were similar, with $38 \%$ of the SVs present in all the sites.

\subsubsection{Differences in Abundance of Taxa by Site}

Several of the abundant taxa were present in the same sample-types from each site; however, their relative abundances differed. For example, Chromatiales was present in all the samples, but they are especially prevalent in manatee grass roots and even more so in sites Hobie 2 and Hobie 3 (Figure 5). Vibrio were mostly abundant in the turtle grass rhizome in site Hobie 1, Desulfobacteraceae was mostly prevalent in manatee grass roots from Hobie 1, unidentified Thiotrichaceae was especially prevalent in 
the rhizomes of sites Hobie 2 and Hobie 3, and unidentified Bacteroidales was more abundant in the sediment control of site Hobie 2.

Despite the similarities in the seawater properties (Table 1), there were also differences per site in the abundance of the microbes of the seawater communities. Flammeovirgaceae is more abundant in the water of Hobie 2 than it is in Hobie 1 or Hobie 3, and Alphaproteobacteria and Pelagibacteraceae are more abundant in both Hobie 1 and Hobie 3 than in Hobie 2 (Figure 5). The phyllosphere communities seemed to be more uniform in the abundances, but turtle grass in Hobie 1 contained less Bacteroidales, Anaerolinea, Deltaproteobacteria, Desulfarculaceae, Desulfobacteraceae, Desulfococcus, Desulfosacina, Thiotrichaceae and Vibrio than the other sites for both species. Turtle grass from Hobie 1 did contain more Piscirickettsiaceae than the other phyllospheres, and manatee grass from Hobie 3 contained more Vibrio.

\subsection{Predictive Metagenome Analysis}

After analyzing the sequencing results through a functional diversity profiling platform, most of the significant genes that were distinct in the different sample types appear to be involved in amino acid metabolism or in transport systems (Table S3). More significant differences were found in the water samples compared to the rest of the sample-types (Table S3; Figure S8). The rhizosphere is predicted to contain more alcohol dehydrogenase and aldehyde oxidoreductase genes, while the sediment communities are predicted to contain more NAD-dependent aldehyde dehydrogenase genes, and the phyllosphere is predicted to contain more thymidylate synthase genes.

\section{Discussion}

\subsection{Microbial Communities Across Seagrass Sample-Types}

Similar studies that have compared the microbiomes of other seagrass species, namely Zostera marina and Zostera japonica [76] and Zostera marina, Zostera noltii and Cymodocea nodosa [77], have found that the microbial communities differ from site to site and sample-type to sample-type, but not from species to species when comparing different geographical locations. Our study on the microbiome of the two seagrasses, T. testudinum and S. filiforme, suggest a similar pattern, revealing clear differences in the microbial communities of each sample-type-leaves, roots, sediment and seawater-and similarities among sampling sites and seagrass species. The communities of the two seagrass species, although very similar, still contained microbes and SVs that were unique to each species. This perhaps is due to the phylogenetic distance of the two seagrass species, where Thalassia belongs to the family Hydrocharitaceae and Syringodium belongs to the family Cymodoceaceae, and subsequent differences in morphology and physiology.

The difference in the community composition of the different plant sample-types is likely due to the different organic compounds provided from each. For example, seagrasses are known to support their phyllosphere communities [78,79] by providing a carbon source for them [38,80]. The age of seagrass leaves seems to also influence the phyllosphere, as Törnblom and Søndergaard 1999 [79] show that the bacterial community of the leaves of $Z$. marina increasingly synthesizes proteins as the leaves age, possibly due to excretions from the plant.

The rhizosphere mainly contains microorganisms involved in the biochemical cycles of nitrogen [81], sulfur [52,81,82], and carbon [38,83-85] that are supported in part by the root exudates. The microbial diversity in the rhizosphere is also influenced by the mostly anoxic conditions of the sediment, oxic microzones around the roots, and the more oxygenated aboveground portions of the plants [52]. A recent study by Martin et al. 2018 [54] shows that sulfur-oxidizing cable bacteria are present near the roots of Zostera muelleri and Halophila ovalis, which also leads to a decreased concentration of sulfide near the roots. Nielsen et al. 2001 [81], who studied Zostera noltii and Spartina maritima, proposed that high sulfate and acetylene reduction rates observed on the rhizomes and roots indicate the importance of these habitats for sulfate-reducing and nitrogen-fixing bacteria. 
This study also indicated that nitrogen-fixing sulfate-reducers provide a nitrogen source for the rhizosphere community as well as for the plant itself. They further suggested that the energy for these cycles is provided by soluble exudates from the seagrass host, such as sucrose. Using stable carbon-isotope ratios, seagrasses have been shown to provide substantial amounts of carbon for their microbiome in Posidonia oceanica and Cymodocea nodosa [84], and T. testudinum [80,85].

\subsection{Site and Species Comparison}

The microbial communities of seagrasses do not differ only across the plant sample-types $[76,77,86-90]$, but are also distinct from the sediment $[77,89,90]$ and seawater $[76,77]$. When comparing the phyllosphere, rhizosphere and sediment communities of T. testudinum and $S$. filiforme, each species has SVs that can be considered "species-specific" (Figure 4a-b). However, more than $50 \%$ of the SVs were common in both species. When comparing the three sampling sites, few SVs were site-specific, while most were common to all (Figure 4d-e, Figure S5). Studies that have found distinct differences in the microbial communities between sampling sites, e.g., Fahimipour et al. 2017 [90], Bengstton et al. 2017 [88] and Cúcio et al. 2016 [77], sampled from locations that were farther apart and more diverse. Likely due to the proximity of our sampling locations, the microbial communities of these two seagrass species were similar from site to site.

\subsection{Water and Phyllosphere}

Interestingly, Fahimipour et al. 2017 [90] found the microbial communities of the leaves and the seawater samples were similar in a world-wide study of Zostera marina. In our study, the seawater communities were vastly different from the plant and sediment communities. The alpha diversity found in the water samples was much less than the diversity of the plant and sediment samples (Figure S1). While the microbial community of the seawater was slightly more related to the leaf-microbes (Figure 2), the seawater samples only shared 3\% of the most abundant SVs with the phyllospheres of both species (Figure 4a). The differences between this study and Fahimipour et al. 2017 [90] might be explained by differences in the studied seagrass species and sampling locations, or due to variations in sampling methods.

The seawater samples in this study were less diverse than the other sample-types and contained genera that were unique to the seawater. Curiously, one of the abundant genera in the seawater was Candidatus Portiera, which is known as an obligate endosymbiont of whiteflies [91]. This candidate genus was also abundant in seawater and brackish water samples in other studies [92-95], and has been found in oysters [96]. The order this genus belongs to, Oceanospirillales, is a common salt-tolerant taxon [97]. The sequence classified in QIIME 2 as Candidatus Portiera likely belongs to an undetermined Oceanospirillales genus, as a check using NCBI's BLAST function suggested.

\subsection{Roots, Sediments, and Rhizomes}

The sediment and the rhizospheres of both seagrass species had very similar microbial communities, but were still distinct enough to cluster mostly separately (Figure $4 \mathrm{~b}$, Figure 2). The proximity of the rhizospheres and sediments might lead to the observed similarities in their communities. The rhizome communities also resembled the root and sediment communities (Figure 4c), but the rhizome contained SVs that were not present in either the sediment or the roots, indicating that its microbial community is distinct. The rhizome is essentially a stem and serves as a means of asexual reproduction where the seagrass clones spread [98]. Since its function differs from the rest of the plant, it seems probable that the microbial community of the rhizome also differs. More research on the microbial community of the rhizome compared to those inhabiting the roots is needed. Many studies on the microbes associated with the rhizome comprise both roots and rhizome as part of the rhizosphere [86,99,100]. Wahbeh and Mahasneh 1984 [101] compare the amount of bacteria on the rhizome, roots and leaves separately and show that bacterial loads differ among sample-types. Insufficient research has since been done on the bacterial composition of the rhizome compared to 
those on roots. Several studies have looked at the different microbial biochemical cycles occurring on the rhizome apart from the roots [53,102-104]; however, few have analyzed the makeup of the microbial community. Recently, Vann et al. 2017 [87] showed that the community of the rhizome is distinct from the community of the roots and leaves in Z. marina. To the best of our knowledge, no studies have investigated the rhizome communities of other seagrass species.

\subsection{Core Microbiome}

Several studies show that the microbial communities of different seagrass species are similar at the same site but vary between different sites and sample-types [76,77]. However, the distinctions in the different sites do not apply to the whole microbial community, and some studies indicate the presence of a core microbiome in seagrasses [76,77,88-90]. Our results are consistent with these findings, considering the geographical proximity of our samples (Figure 1) and the similarities between the microbiome in these sites (Figure 4d-e, Figure 5, Figure S5). Due to the overlapping microbial communities of the two seagrass species, we combined the two species when considering the SVs in the core microbiome. The abundance of the microbes differs between species in the same site (Figure 5). For instance, Chromatiales is clearly more abundant in the manatee grass samples than it is in the turtle grass samples. Varying ratios might also hold true in the core microbiomes. The relative abundance of certain taxa might be species specific or the result of differing environmental conditions in the different locations of the seagrasses.

The most abundant taxa in our samples were also commonly found in other studies. For instance, Cúcio et al. 2016 [77] found that the most abundant taxa in all three seagrasses (Z. marina, Z. noltii and C. nodosa) were Gammaproteobacteria, Deltaproteobacteria, Bacteroidia, Epsilonproteobacteria, Anaerolineae, Acidimicrobiia, and Alphaproteobacteria. In the rhizosphere, the most abundant taxa were Epsilonproteobacteria (family Helicobacteraceae), Acidimicrobiia, Gammaproteobacteria (order Chromatiales), Deltaproteobacteria (genus Desulfococcus), and Clostridia (order Clostridiales). Ettinger et al. 2017 [89] found that Z. marina contained Bacteroidia, Clostridia, Flavobacteriia, Saprospirae, Anaerolineae as well as Alpha-, Delta-, Epsilon- and Gammaproteobacteria in its microbiome. Bengtsson et al. 2017 [88] found the abundant sequence variants to be Proteobacteria, Bacteriodetes, Cytophagia, Cyanobacteria, Verrucomicrobia, Planctomycetes, Plastids, and Actinobacteria in the leaves of Z. marina. In our study, we found Gammaproteobacteria in all our samples, though they were slightly more abundant in the roots and rhizome, Deltaproteobacteria in all the samples except seawater, and Alphaproteobacteria and Flavobacteriia mostly in seawater and phyllospheres (Figure 5). Table 3 shows a comparison of the abundant taxa in several studies and in our study.

The core microbiome of seagrasses, as the current and cited studies suggest, is likely composed of Alphaproteobacteria and Gammaproteobacteria (present in all the studies), Acidimicrobiia, Clostridia, and Deltaproteobacteria (present in six out of seven) and Betaproteobacteria (present in five out of seven studies) (Table 3). In our study, Betaproteobacteria and Clostridia were also present, although they were not abundant (data not shown). These classes might represent species-specific taxa that are mostly present in Z. marina and not as prevalent in T. testudinum or S. filiforme. The location of the sampling site might also contribute to the presence or absence of these taxa. Betaproteobacteria and Clostridia were not considered abundant in some of the other studies despite analyzing the same seagrass species $([89,90]$, Table 3). Cúcio et al. 2016 [77] suggests that the core microbiome should be present in all the species of seagrasses. It is possible that the core microbiome may not be exactly the same for all seagrasses since environmental conditions play a major part in the abundance of these microbes [86]. In order to not exclude microbes that were outcompeted or overshadowed by other opportunistic 'non-members' of the core microbiome under unfavorable conditions, as has been seen in other plants [105], we should study the microbiome of seagrasses that are not under stress when considering the core microbiome. 
Table 3. Comparison of abundant bacteria found in different seagrass studies around the world. Taxa level is based on how the authors ranked their taxa. (p: phylum; c: class; o: order; f: family; nma: not most abundant (most abundant taxa make up more than $1 \%$ of the sequences); rfd: removed from data; + present in high relative abundance).

\begin{tabular}{|c|c|c|c|c|c|c|c|c|c|}
\hline Taxa & Level & Higher Rank & This Study & $\begin{array}{c}\text { Cúcio et al. } 2016 \\
\text { [77] }\end{array}$ & $\begin{array}{c}\text { Mejia et al. } \\
2016 \text { [86] }\end{array}$ & $\begin{array}{l}\text { Ettinger et al. } \\
\text { 2017 [89] }\end{array}$ & $\begin{array}{c}\text { Fahimipour et al. } \\
2017 \text { [90] }\end{array}$ & $\begin{array}{l}\text { Crump et al. } \\
2018[76]\end{array}$ & $\begin{array}{c}\text { Bengtsson et al. } \\
2017[88]\end{array}$ \\
\hline Acidimicrobiia & c & p Actinobacteria & + & + & + & & + & + & + \\
\hline Acidobacteria & $\mathrm{p}$ & & nma & + & & & & & + \\
\hline Alphaproteobacteria & c & p Proteobacteria & + & + & + & + & + & + & + \\
\hline Alteromonadales OM60 & $o / f$ & c Gammaproteobacteria & + & & & + & & & \\
\hline Anaerolineae & $\mathrm{c}$ & p Chloroflexi & + & + & & & & & \\
\hline Bacteroidia & c & p Bacteroidetes & + & & + & + & & + & \\
\hline Betaproteobacteria & c & p Proteobacteria & nma & & + & & + & + & + \\
\hline Caldithrixae & c & p Bacteroidetes & + & + & & & & & \\
\hline Campylobacterales & o & c Epsilonproteobacteria & nma & & & + & & & \\
\hline Chloroflexi & $\mathrm{p}$ & \multirow{3}{*}{$\mathrm{p}$ Firmicutes } & + & + & + & & & & + \\
\hline Clostridia & c & & \multirow{2}{*}{$\begin{array}{c}\text { nma } \\
\text { nma (chloroplasts } \\
\text { rfd) }\end{array}$} & \multirow[t]{2}{*}{+} & + & + & & + & + \\
\hline Cyanobacteria & $\mathrm{p}$ & & & & + & & & & + \\
\hline Cytophagia & c & \multirow[t]{3}{*}{$\mathrm{p}$ Bacteroidetes } & + & + & & & & & + \\
\hline Deinococcus-Thermus & $\mathrm{p}$ & & & & & & & & + \\
\hline Deltaproteobacteria & c & & + & + & + & + & + & + & \\
\hline Desulfobacterales & o & \multirow{2}{*}{$\begin{array}{l}\text { c Deltaproteobacteria } \\
\text { o Desulfovibrionales, } \\
\text { c Deltaproteobacteria }\end{array}$} & + & & & + & & & \\
\hline Desulfovibrionaceae & $\mathrm{f}$ & & nma & & & & + & & \\
\hline Desulfuromonadaceae & $\mathrm{f}$ & $\begin{array}{l}\text { o Desulfuromonadales, } \\
\text { c Deltaproteobacteria }\end{array}$ & nma & & & & + & & \\
\hline Epsilonproteobacteria & c & p Proteobacteria & nma & + & + & & & + & \\
\hline Flavobacteriia & c & p Bacteroidetes & + & & + & + & & & + \\
\hline Gammaproteobacteria & c & p Proteobacteria & + & + & + & + & + & + & + \\
\hline Gemmatimonadetes & $\mathrm{p}$ & & nma & + & & & & & + \\
\hline Phycisphaerae & $\mathrm{c}$ & p Planctomycetes & nma & & + & & & & \\
\hline $\begin{array}{l}\text { Plantomycetia } \\
\text { Plastid }\end{array}$ & $\begin{array}{c}\mathrm{c} \\
\text { plant }\end{array}$ & $\begin{array}{l}\text { p Planctomycetes } \\
\text { Chloroplasts }\end{array}$ & + & & + & & + & & + \\
\hline $\begin{array}{c}\text { Plastid } \\
\text { Saprospirae }\end{array}$ & $\mathrm{f}$ & $\begin{array}{l}\text { Chloroplasts } \\
\text { c Sphingobacteria, }\end{array}$ & $+(\mathrm{rfd})$ & & & + & & & + \\
\hline Saprospirae & c & o Sphingobacteriales & + & & & + & & & \\
\hline $\begin{array}{l}\text { Sphingobacteriia } \\
\text { Spirochaetes }\end{array}$ & $\begin{array}{l}c \\
p\end{array}$ & p Bacteroidetes & nma & & + & & & + & + \\
\hline \multirow{4}{*}{$\begin{array}{c}\text { Verrucomicrobia } \\
\text { WS3 }\end{array}$} & p & & $\begin{array}{c}+ \\
\text { nma }\end{array}$ & & + & & & + & + \\
\hline & $\mathrm{p}$ & & nma & + & + & & & & \\
\hline & & Seagrass Species & $\begin{array}{l}\text { T. testudinum and } \\
\text { S. filiforme }\end{array}$ & $\begin{array}{l}\text { Z. marina, Z. noltii } \\
\text { and C. nodosa }\end{array}$ & H. stipulacea & Z. marina & Z. marina & $\begin{array}{l}\text { Z. marina and } \\
\text { Z. japonica }\end{array}$ & Z. marina \\
\hline & & Location & Key Biscayne, FL & $\begin{array}{l}\text { Culatra Island, } \\
\text { Portugal }\end{array}$ & Israel & $\begin{array}{l}\text { Bodega bay, } \\
\text { California }\end{array}$ & World wide & $\begin{array}{l}\text { Netarts Bay or } \\
\text { USA }\end{array}$ & $\begin{array}{l}\text { Hiddensee, } \\
\text { Germany }\end{array}$ \\
\hline
\end{tabular}




\subsection{Predictive Metabolism}

The sequences were run through a predictive metagenomics analysis program, revealing that many of the significantly distinct genes in the different sample-types were associated with amino acid metabolism or transporter proteins (Table S3; Figure S8). Only 30 out of more than 6000 genes were predicted to be significantly different in their abundance per sample-type, and most of these were prevalent in the water, which is likely due to its very different microbial community compared to other sample-types' (Table S3; Figure 2). One of the few genes that were predicted to be more significant in the rhizosphere was alcohol dehydrogenase. As discussed by Cúcio and colleagues [77], bacteria in the class Deltaproteobacteria, namely Desulfobacteracea and Desulfobulbacea, are known to use sulfates or sulfite as electron acceptors to oxidize alcohol into carbon dioxide. In seagrass roots, there is a lack of oxygen during the night cycle, which encourages the plant to ferment, releasing ethanol into the surrounding environment $[77,106]$. These bacteria likely utilize the ethanol released from fermentation in the rhizosphere at nighttime, and release hydrogen sulfide in the daytime [77,107]. Some Desulfococcus, which are known sulfate-reducers, also possess the genes for alcohol dehydrogenase [108]. The abundance of these Deltaproteobacteria in our rhizosphere samples (Figure 5) likely explains the predicted significant differential abundance of alcohol dehydrogenase genes in our rhizosphere samples.

\subsection{Processing Methods Comparison}

Sonication has been used successfully to detach epiphytes from macrophytes [59,109]; however, it is not commonly used in recent seagrass studies. More common techniques include directly extracting DNA from the samples $[87,89,90]$, rinsing samples before processing $[76,77,86,88]$, and scraping samples off the leaves with cotton swabs [88]. Most of these methods involve pelleting the cells and then processing the samples. Our methods included sonications and vacuum-filtration. Eva Nilsson 2001 [110] suggests several techniques for sampling epiphytes from macrophytes including sonicating, scraping, shaking and chemical treatments. Because there is no standard protocol to study the seagrass microbiome, the different methods used may lead to varying results between studies.

\section{Conclusions}

In conclusion, the microbial communities of the different sample-types differ from one another, but are similar between the two species of seagrasses. Although some of the taxa were present in most of the sample-types, the relative abundance of the taxa differed from species to species as well as from sample-type to sample-type. Some of the most abundant organisms found in the communities of these seagrasses are involved in important biogeochemical cycles that can benefit their seagrass host, including carbon, nitrogen, and sulfur cycles. When comparing our results with other studies, there is strong evidence that a core microbiome exists for seagrasses.

Supplementary Materials: The following are available online at http:/ /www.mdpi.com/2076-2607/7/1/4/s1, Figure S1: Boxplots of alpha diversity based on phylogenetic diversity (Faith's PD), Figure S2: Rarefaction curve analysis of the sequences variants of all samples, Figure S3: Venn diagram comparing the most common SVs of the phyllospheres and rhizospheres of both species and the turtle grass rhizomes, Figure S4: Venn diagrams comparing the most common SVs of the seagrass samples from each sampling sites, Hobie 1, Hobie 2 and Hobie 3, Figure S5: Venn diagram comparing the most common SVs of the seawater samples from each sampling site, Hobie 1, Hobie 2 and Hobie 3, Figure S6: Relative abundance of the classes comprising more than 1\% of the bacterial sequences in each sample. Taxa are classified to the lowest rank possible according the classifier, Figure S7: Relative abundance of the genera comprising between $0.1 \%$ and $1 \%$ of the bacterial sequences in each sample, Figure S8: Linear discriminant analysis (LDA) scores of the top 25 most significant genes from the predictive metagenome of the microbial communities in each sample type, Table S1: Pairwise analysis of sample types. (Kruskal Wallis one-way ANOVA test using Faith PD alpha diversity; q-values are adjusted $p$-values with a Benjamin \& Hochberg correction), Table S2: Pairwise analysis of seagrass species and the sediment controls. (Kruskal Wallis one-way ANOVA test using Faith PD alpha diversity; q-values are adjusted $p$-values with a Benjamin \& Hochberg correction), Table S3: Linear discriminant analysis effect size (LEfSe) of the most significant genes from the predictive metagenome of the microbial communities in each sample type. 
Author Contributions: Conceptualization, U.S.; methodology, P.L. and K.U.; software, P.L.; validation, U.S., P.L. and K.U.; formal analysis, P.L. and K.U..; investigation, P.L and K.U.; resources, U.S.; data curation, P.L. and K.U.; writing—original draft preparation, K.U.; writing—review and editing, U.S. and P.L.; visualization, K.U.; supervision, U.S.; project administration, U.S.; funding acquisition, U.S.

Funding: This research was supported by start-up funds of the University of Florida to U.S. Additional funding to support the publication of this manuscript was provided to U.S. by the USDA National Institute of Food and Agriculture under Hatch project FLA-FTL-0 05631.

Acknowledgments: We thank Seemanti Chakrabarti for managing the supplies used for this study. We thank Reina Tong for help with Figure 1.

Conflicts of Interest: The authors declare no conflicts of interest.

\section{References}

1. Schubert, N.; Demes, K.W. Phenotypic Plasticity in the Marine Angiosperm Halophila Decipiens (Hydrocharitaceae, Streptophyta). Mar. Ecol. Progress Ser. 2017, 575, 81-93. [CrossRef]

2. Spalding, M.; Taylor, M.; Ravilious, C.; Short, F.; Green, E. The distribution and status of seagrasses. In World Atlas of Seagrasses; Green, E.P., Short, F.T., Eds.; University of California Press: Berkeley, CA, USA, 2003; pp. 5-26.

3. Duarte, C.M.; Middelburg, J.J.; Caraco, N. Major Role of Marine Vegetation on the Oceanic Carbon Cycle. Biogeosciences 2005, 2, 1-8. [CrossRef]

4. Charpy-Roubaud, C.; Sournia, A. The Comparative Estimation of Phytoplanktonic, Microphytobenthic and Macrophytobenthic Primary Production in the Oceans. Mar. Microb. Food Webs 1990, 4, 31-57.

5. Ugarelli, K.; Chakrabarti, S.; Laas, P.; Stingl, U. The Seagrass Holobiont and Its Microbiome. Microorganisms 2017, 5, 81. [CrossRef]

6. Mazarrasa, I.; Marba, N.; Lovelock, C.E.; Serrano, O.; Lavery, P.S.; Fourqurean, J.W.; Kennedy, H.; Mateo, M.A.; Krause-Jensen, D.; Steven, A.D.L.; et al. Seagrass Meadows as a Globally Significant Carbonate Reservoir. Biogeosciences 2015, 12, 4993-5003. [CrossRef]

7. Reynolds, P.L. Seagrass and Seagrass Beds. Available online: http:/ /ocean.si.edu/seagrass-and-seagrassbeds (accessed on 1 November 2018).

8. Guannel, G.; Arkema, K.; Ruggiero, P.; Verutes, G. The Power of Three: Coral Reefs, Seagrasses and Mangroves Protect Coastal Regions and Increase Their Resilience. PLoS ONE 2016, 11, e0158094. [CrossRef]

9. Christianen, M.J.A.; van Belzen, J.; Herman, P.M.J.; van Katwijk, M.M.; Lamers, L.P.M.; van Leent, P.J.M.; Bouma, T.J. Low-Canopy Seagrass Beds Still Provide Important Coastal Protection Services. PLoS ONE 2013, 8, e62413. [CrossRef]

10. Kannan, R.R.R.; Arumugam, R.; Anantharaman, P. Antibacterial Potential of Three Seagrasses against Human Pathogens. Asian Pac. J. Trop. Med. 2010, 3, 890-893. [CrossRef]

11. Castelblanco-Martinez, D.N.; Barba, E.; Schmitter-Soto, J.J.; Hernandez-Arana, H.A.; Morales-Vela, B. The Trophic Role of the Endangered Caribbean Manatee Trichechus manatus in an Estuary with Low Abundance of Seagrass. Estuaries Coasts 2012, 35, 60-77. [CrossRef]

12. Best, R.C. Foods and Feeding Habits of Wild and Captive Sirenia. Mamm. Rev. 1981, 11, 3-29. [CrossRef]

13. Seagrasses. Available online: http://myfwc.com/research/habitat/seagrasses/\%0A (accessed on 15 October 2018).

14. Gullstrom, M.; de la Torre-Castro, M.; Bandeira, S.O.; Bjork, M.; Dahlberg, M.; Kautsky, N.; Ronnback, P.; Ohman, M.C. Seagrass Ecosystems in the Western Indian Ocean. Ambio 2002, 31, 588-596. [CrossRef]

15. Bertelli, C.M.; Unsworth, R.K.F. Protecting the Hand That Feeds Us: Seagrass (Zostera marina) Serves as Commercial Juvenile Fish Habitat. Mar. Pollut. Bull. 2014, 83, 425-429. [CrossRef]

16. Lilley, R.J.; Unsworth, R.K.F. Atlantic Cod (Gadus morhua) Benefits from the Availability of Seagrass (Zostera marina) Nursery Habitat. Glob. Ecol. Conserv. 2014, 2, 367-377. [CrossRef]

17. Waycott, M.; Duarte, C.M.; Carruthers, T.J.B.; Orth, R.J.; Dennison, W.C.; Olyarnik, S.; Calladine, A.; Fourqurean, J.W.; Heck, K.L.; Hughes, A.R.; et al. Accelerating Loss of Seagrasses across the Globe Threatens Coastal Ecosystems. Proc. Natl. Acad. Sci. USA 2009, 106, 12377-12381. [CrossRef] 
18. Terrados, J.; Duarte, C.M.; Fortes, M.D.; Borum, J.; Agawin, N.S.R.; Bach, S.; Thampanya, U.; Kamp-Nielsen, L.; Kenworthy, W.J.; Geertz-Hansen, O.; et al. Changes in Community Structure and Biomass of Seagrass Communities along Gradients of Siltation in SE Asia. Estuar. Coast. Shelf Sci. 1998, 46, 757-768. [CrossRef]

19. De Falco, G.; Baroli, M.; Murru, E.; Piergallini, G.; Cancemi, G. Sediment Analysis Evidences Two Different Depositional Phenomena Influencing Seagrass Distribution in the Gulf of Oristano (Sardinia, Western Mediterranean). J. Coast. Res. 2006, 22, 1043-1050. [CrossRef]

20. Cavazza, W.; Immordino, F.; Moretti, L.; Peirano, A.; Pironi, A.; Ruggiero, F. Sedimentological Parameters and Seagrasses Distributions as Indicators of Anthropogenic Coastal Degradation at Monterosso Bay (Ligurian Sea, NW Italy). J. Coast. Res. 2000, 16, 295-305.

21. Dahl, M.; Deyanova, D.; Lyimo, L.D.; Naslund, J.; Samuelsson, G.S.; Mtolera, M.S.P.; Bjork, M.; Gullstrom, M. Effects of Shading and Simulated Grazing on Carbon Sequestration in a Tropical Seagrass Meadow. J. Ecol. 2016, 104, 654-664. [CrossRef]

22. Jones, B.L.; Unsworth, R.K.F. The Perilous State of Seagrass in the British Isles. R. Soc. Open Sci. 2016, 3, 150596. [CrossRef]

23. Bergmann, N.; Winters, G.; Rauch, G.; Eizaguirre, C.; Gu, J.; Nelle, P.; Fricke, B.; Reusch, T.B.H. Population-Specificity of Heat Stress Gene Induction in Northern and Southern Eelgrass Zostera marina Populations under Simulated Global Warming. Mol. Ecol. 2010, 19, 2870-2883. [CrossRef]

24. Burkholder, J.M.; Tomasko, D.A.; Touchette, B.W. Seagrasses and Eutrophication. J. Exp. Mar. Biol. Ecol. 2007, 350, 46-72. [CrossRef]

25. Walker, D.I.; McComb, A.J. Seagrass Degradation in Australian Coastal Waters. Mar. Pollut. Bull. 1992, 25, 191-195. [CrossRef]

26. Unsworth, R.K.F.; Jones, B.L.; Cullen-Unsworth, L.C. Seagrass Meadows Are Threatened by Expected Loss of Peatlands in Indonesia. Glob. Chang. Biol. 2016, 22, 2957-2958. [CrossRef]

27. Connell, S.D.; Fernandes, M.; Burnell, O.W.; Doubleday, Z.A.; Griffin, K.J.; Irving, A.D.; Leung, J.Y.S.; Owen, S.; Russell, B.D.; Falkenberg, L.J. Testing for Thresholds of Ecosystem Collapse in Seagrass Meadows. Conserv. Biol. 2017, 31, 1196-1201. [CrossRef]

28. Duarte, C.M. Submerged Aquatic Vegetation in Relation to Different Nutrient Regimes. Ophelia 1995, 41, 87-112. [CrossRef]

29. Mabrouk, L.; Hamza, A.; Ben Brahim, M.; Bradai, M.N. Variability in the Structure of Epiphyte Assemblages on Leaves and Rhizomes of Posidonia Oceanica in Relation to Human Disturbances in a Seagrass Meadow off Tunisia. Aquat. Bot. 2013, 108, 33-40. [CrossRef]

30. Short, F.; Green, E.P. World Atlas of Seagrasses; University of California Press: Berkeley, CA, USA, 2003.

31. Larkum, A.W.D.D.; Orth, R.J.; Duarte, C.M. Seagrasses: Biology, Ecology, and Conservation; Springer: Cham, The Netherlands, 2006.

32. Borum, J.; Pedersen, O.; Greve, T.M.; Frankovich, T.A.; Zieman, J.C.; Fourqurean, J.W.; Madden, C.J. The Potential Role of Plant Oxygen and Sulphide Dynamics in Die-off Events of the Tropical Seagrass, Thalassia testudinum. J. Ecol. 2005, 93, 148-158. [CrossRef]

33. Carlson, P.R.; Yarbro, L.A.; Barber, T.R. Relationship of Sediment Sulfide to Mortality of Thalassia-testudinum in Florida Bay. Bull. Mar. Sci. 1994, 54, 733-746.

34. Brodersen, K.E.; Nielsen, D.A.; Ralph, P.J.; Kuhl, M. Oxic Microshield and Local PH Enhancement Protects Zostera muelleri from Sediment Derived Hydrogen Sulphide. New Phytol. 2015, 205, 1264-1276. [CrossRef]

35. Holmer, M.; Pedersen, O.; Krause-Jensen, D.; Olesen, B.; Hedegård Petersen, M.; Schopmeyer, S.; Koch, M.; Lomstein, B.A.; Jensen, H.S. Sulfide Intrusion in the Tropical Seagrasses Thalassia testudinum and Syringodium filiforme. Estuar. Coast. Shelf Sci. 2009, 85, 319-326. [CrossRef]

36. Hasler-Sheetal, H.; Holmer, M. Sulfide Intrusion and Detoxification in the Seagrass Zostera marina. PLoS ONE 2015, 10, e0129136. [CrossRef]

37. Vandenkoornhuyse, P.; Quaiser, A.; Duhamel, M.; Le Van, A.; Dufresne, A. The Importance of the Microbiome of the Plant Holobiont. New Phytol. 2015, 206, 1196-1206. [CrossRef]

38. Moriarty, D.J.W.; Iverson, R.L.; Pollard, P.C. Exudation of Organic Carbon by the Seagrass Halodule wrightii Aschers. And Its Effect on Bacterial Growth in the Sediment. J. Exp. Mar. Biol. Ecol. 1986, 96, 115-126. [CrossRef] 
39. Penhale, P.A.; Smith, W.O. Excretion of Dissolved Organic Carbon by Eelgrass (Zostera marina) and Its Epiphytes. Limnol. Oceanogr. 1977, 22, 400-407. [CrossRef]

40. Smith, G.W.; Hayasaka, S.S.; Thayer, G.W. Ammonification of Amino Acids by the Rhizoplane Microflora of Zostera marina L. and Halodule wrightii Aschers. Bot. Mar. 1984, 27, 23-28. [CrossRef]

41. Wetzel, R.G.; Penhale, P.A. Transport of Carbon and Excretion of Dissolved Organic Carbon by Leaves and Roots/Rhizomes in Seagrasses and Their Epiphytes. Aquat. Bot. 1979, 6, 149-158. [CrossRef]

42. Patriquin, D.; Knowles, R. Nitrogen Fixation in the Rhizosphere of Marine Angiosperms. Mar. Biol. 1972, 16, 49-58. [CrossRef]

43. Sun, F.; Zhang, X.; Zhang, Q.; Liu, F.; Zhang, J.; Gong, J. Seagrass (Zostera marina) Colonization Promotes the Accumulation of Diazotrophic Bacteria and Alters the Relative Abundances of Specific Bacterial Lineages Involved in Benthic Carbon and Sulfur Cycling. Appl. Environ. Microbiol. 2015, 81, 6901-6914. [CrossRef]

44. O'Donohue, M.J.; Moriarty, D.J.; Rae, I.C. Nitrogen Fixation in Sediments and the Rhizosphere of the Seagrass Zostera capricorni. Microb. Ecol. 1991, 22, 53-64. [CrossRef]

45. Welsh, D. Nitrogen Fixation in Seagrass Meadows: Regulation, Plant \pm Bacteria Interactions and Significance to Primary Productivity. Ecol. Lett. 2000, 3, 58-71. [CrossRef]

46. Cole, L.W.; McGlathery, K.J. Nitrogen Fixation in Restored Eelgrass Meadows. Mar. Ecol. Prog. Ser. 2012, 448, 235-246. [CrossRef]

47. Caffrey, J.; Kemp, W. Nitrogen Cycling in Sediments with Estuarine Populations of Potamogeton perfoliatus and Zostera marina. Mar. Ecol. Prog. Ser. 1990, 66, 147-160. [CrossRef]

48. Smith, R.D.; Dennison, W.C.; Alberte, R.S. Role of Seagrass Photosynthesis in Root Aerobic Processes. Plant Physiol. 1984, 74, 1055-1058. [CrossRef]

49. Agawin, N.S.R.; Ferriol, P.; Cryer, C.; Alcon, E.; Busquets, A.; Sintes, E.; Vidal, C.; Moyà, G. Significant Nitrogen Fixation Activity Associated with the Phyllosphere of Mediterranean Seagrass Posidonia oceanica: First Report. Mar. Ecol. Prog. Ser. 2016, 551, 53-62. [CrossRef]

50. Smith, A.C.; Kostka, J.E.; Devereux, R.; Yates, D.F. Seasonal Composition and Activity of Sulfate-Reducing Prokaryotic Communities in Seagrass Bed Sediments. Aquat. Microb. Ecol. 2004, 37, 183-195. [CrossRef]

51. Isaksen, M.F.; Finster, K. Sulphate Reduction in the Root Zone of the Seagrass Zostera noltii on the Intertidal Flats of a Coastal Lagoon (Arcachon, France). Mar. Ecol. Prog. Ser. 1996, 137, 187-194. [CrossRef]

52. Lee, K.S.; Dunton, K.H. Diurnal Changes in Pore Water Sulfide Concentrations in the Seagrass Thalassia testudinum Beds: The Effects of Seagrasses on Sulfide Dynamics. J. Exp. Mar. Biol. Ecol. 2000, 255, 201-214. [CrossRef]

53. Blaabjerg, V.; Finster, K. Sulphate Reduction Associated with Roots and Rhizomes of the Marine Macrophyte Zostera marina. Aquat. Microb. Ecol. 1998, 15, 311-314. [CrossRef]

54. Martin, B.C.; Bougoure, J.; Ryan, M.H.; Bennett, W.W.; Colmer, T.D.; Joyce, N.K.; Olsen, Y.S.; Kendrick, G.A. Oxygen Loss from Seagrass Roots Coincides with Colonisation of Sulphide-Oxidising Cable Bacteria and Reduces Sulphide Stress. ISME J. 2018. [CrossRef]

55. Dineen, J. Thalassia testudinum. Available online: http://www.sms.si.edu/irlspec/thalas_testud.htm (accessed on 15 October 2018).

56. Dawes, C. The Dynamic Seagrasses of the Gulf of Mexico and Florida Coasts. In Proceedings of the Symposium on Subtropicaltropical Seagrasses of the Southeastern United States; Durako, M.J., Phillips, R.C., Lewis, R.I., Eds.; Florida Department of Natural Resources Bureau of Marine Research: St. Petersburg, Russia, 1987; pp. 25-38.

57. Moore, D.R. Distribution of the Sea Grass, Thalassia, in the United States. Bull. Mar. Sci. 1963, 13, 329-342.

58. Short, F.T.; Carruthers, T.J.R.; van Tussenbroek, B.; Zieman, J. Syringodium filiforme. Available online: http:/ / dx.doi.org/10.2305/IUCN.UK.2010-3.RLTS.T173378A7003203.en (accessed on 15 October 2018).

59. Weidner, S.; Arnold, W.; Pühler, A. Diversity of Uncultured Microorganisms Associated with the Seagrass Halophila stipulacea Estimated by Restriction Fragment Length Polymorphism Analysis of PCR-Amplified 16s RRNA Genes. Appl. Environ. Microbiol. 1996, 62, 766-771.

60. White, L.J.; Brözel, V.S.; Subramanian, S. Isolation of Rhizosphere Bacterial Communities from Soil. Bio-Protocol 2015, 5. [CrossRef]

61. Caporaso, J.G.; Lauber, C.L.; Walters, W.A.; Berg-Lyons, D.; Lozupone, C.A.; Turnbaugh, P.J.; Fierer, N.; Knight, R. Global Patterns of 16S RRNA Diversity at a Depth of Millions of Sequences per Sample. Proc. Natl. Acad. Sci. USA 2011, 108 (Suppl. 1), 4516-4522. [CrossRef]

62. Available online: QIIME2https:/ / qiime2.org/ (accessed on 15 October 2018). 
63. Caporaso, J.G.; Kuczynski, J.; Stombaugh, J.; Bittinger, K.; Bushman, F.D.; Costello, E.K.; Fierer, N.; Peña, A.G.; Goodrich, J.K.; Gordon, J.I.; et al. QIIME Allows Analysis of High-Throughput Community Sequencing Data. Nat. Methods 2010, 7, 335. [CrossRef]

64. Callahan, B.J.; McMurdie, P.J.; Rosen, M.J.; Han, A.W.; Johnson, A.J.A.; Holmes, S.P. DADA2: High-Resolution Sample Inference from Illumina Amplicon Data. Nat. Methods 2016, 13, 581. [CrossRef]

65. Yilmaz, P.; Parfrey, L.W.; Yarza, P.; Gerken, J.; Pruesse, E.; Quast, C.; Schweer, T.; Peplies, J.; Ludwig, W.; Glöckner, F.O. The SILVA and “All-Species Living Tree Project (LTP)” Taxonomic Frameworks. Nucleic Acids Res. 2014, 42, D643-D648. [CrossRef]

66. Bokulich, N.A.; Kaehler, B.D.; Rideout, J.R.; Dillon, M.; Bolyen, E.; Knight, R.; Huttley, G.A.; Gregory Caporaso, J. Optimizing Taxonomic Classification of Marker-Gene Amplicon Sequences with QIIME 2's Q2-Feature-Classifier Plugin. Microbiome 2018, 6, 90. [CrossRef]

67. R Core Team. R: A Language and Environment for Statistical Computing; R Foundation for Statistical Computing: Vienna, Austria, 2013.

68. Charif, D.; Lobry, J.R. Seqin $\{R\}$ 1.0-2: A Contributed Package to the $\{R\}$ Project for Statistical Computing Devoted to Biological Sequences Retrieval and Analysis. In Structural Approaches to Sequence Evolution: Molecules, Networks, Populations; Bastolla, U., Port, M., Roman, H.E., Vendruscolo, M., Eds.; Springer: New York, NY, USA, 2007; pp. 207-232.

69. Walesiak, M.; Dudek, A. ClusterSim: Searching for Optimal Clustering Procedure for a Data Set. 2017. Available online: https:/ / rdrr.io/cran/clusterSim/ (accessed on 15 August 2018).

70. Wickham, H. Reshaping Data with the \{reshape\} Package. J. Stat. Softw. 2007, 21, 1-20. [CrossRef]

71. Wickham, H. Ggplot2: Elegant Graphics for Data Analysis. J Stat Softw 2010, 35, 65-88.

72. Chen, H. VennDiagram: Generate High-Resolution Venn and Euler Plots. 2018. Available online: https: //rdrr.io/cran/VennDiagram/ (accessed on 15 October 2018).

73. Oksanen, J.; Blanchet, F.; Guillaume Friendly, M.; Kindt, R.; Legendre, P.; McGlinn, D.; Minchin, P.R.; O'Hara, R.B.; Simpson, G.L.; Solymos, P.; et al. Vegan: Community Ecology Package. 2018. Available online: https:/ / cran.r-project.org/web/packages/vegan/vegan.pdf (accessed on 15 October 2018).

74. Dhariwal, A.; Chong, J.; Habib, S.; King, I.L.; Agellon, L.B.; Xia, J. MicrobiomeAnalyst: A Web-Based Tool for Comprehensive Statistical, Visual and Meta-Analysis of Microbiome Data. Nucleic Acids Res. 2017, 45, W180-W188. [CrossRef]

75. ArcGIS and ArcMap, version 10.5.1, Esri: Redlands, CA, USA, 2017.

76. Crump, B.C.; Wojahn, J.M.; Tomas, F.; Mueller, R.S. Metatranscriptomics and Amplicon Sequencing Reveal Mutualisms in Seagrass Microbiomes. Front. Microbiol. 2018, 9, 388. [CrossRef]

77. Cúcio, C.; Engelen, A.H.; Costa, R.; Muyzer, G. Rhizosphere Microbiomes of European + Seagrasses Are Selected by the Plant, but Are Not Species Specific. Front. Microbiol. 2016, 7, 1-15. [CrossRef]

78. Kirchman, D.; Mazzella, L.; Alberte, R.; Mitchell, R. Epiphytic Bacterial Production on Zostera marina. Mar. Ecol. Prog. Ser. 1984, 15, 117-123. [CrossRef]

79. Törnblom, E.; Søndergaard, M. Seasonal Dynamics of Bacterial Biomass and Production on Eelgrass Zostera marina Leaves. Mar. Ecol. Prog. Ser. 1999, 179, 231-240. [CrossRef]

80. Williams, C.J.; Jaffé, R.; Anderson, W.T.; Jochem, F.J. Importance of Seagrass as a Carbon Source for Heterotrophic Bacteria in a Subtropical Estuary (Florida Bay). Estuar. Coast. Shelf Sci. 2009, 85, 507-514. [CrossRef]

81. Nielsen, L.B.; Finster, K.; Welsh, D.T.; Donelly, A.; Herbert, R.A.; De Wit, R.; Lomstein, B.A.A. Sulphate Reduction and Nitrogen Fixation Rates Associated with Roots, Rhizomes and Sediments from Zostera noltii and Spartina maritima Meadows. Environ.Microbiol. 2001, 3, 63-71. [CrossRef]

82. Kim, B.; Choi, A.; Lee, K.S.; Kang, C.K.; Hyun, J.H. Sulfate Reduction and Sulfur Cycles at Two Seagrass Beds Inhabited by Cold Affinity Zostera marina and Warm Affinity Halophila nipponica in Temperate Coastal Waters. Estuar. Coasts 2017, 40, 1346-1357. [CrossRef]

83. Holmer, M.; Andersen, F.O.; Nielsen, S.L.; Boschker, H.T.S. The Importance of Mineralization Based on Sulfate Reduction for Nutrient Regeneration in Tropical Seagrass Sediments. Aquat. Bot. 2001, 71, 1-17. [CrossRef]

84. Holmer, M.; Duarte, C.M.; Boschker, H.T.S.; Barrón, C. Carbon Cycling and Bacterial Carbon Sources in Pristine and Impacted Mediterranean Seagrass Sediments. Aquat. Microb. Ecol. 2004, 36, 227-237. [CrossRef] 
85. Jones, W.B.; Cifuentes, L.A.; Kaldy, J.E. Stable Carbon Isotope Evidence for Coupling between Sedimentary Bacteria and Seagrasses in a Sub-Tropical Lagoon. Mar. Ecol. Prog. Ser. 2003, 255, 15-25. [CrossRef]

86. Mejia, A.Y.; Rotini, A.; Lacasella, F.; Bookman, R.; Thaller, M.C.; Shem-Tov, R.; Winters, G.; Migliore, L. Assessing the Ecological Status of Seagrasses Using Morphology, Biochemical Descriptors and Microbial Community Analyses. A Study in Halophila stipulacea (Forsk.) Aschers Meadows in the Northern Red Sea. Ecol. Indic. 2016, 60, 1150-1153. [CrossRef]

87. Vann, L.E.; Holland-Moritz, H.; Ettinger, C.; Lang, J.; Eisen, J.A. Natural Variation in Plants: A Survey of Host and Microbe Variation. Proquest Diss. Theses 2017, 71-104. [CrossRef]

88. Bengtsson, M.M.; Bühler, A.; Brauer, A.; Dahlke, S.; Schubert, H.; Blindow, I. Eelgrass Leaf Surface Microbiomes Are Locally Variable and Highly Correlated with Epibiotic Eukaryotes. Front. Microbiol. 2017, 8, 1-11. [CrossRef]

89. Ettinger, C.L.; Voerman, S.E.; Lang, J.M.; Stachowicz, J.J.; Eisen, J.A. Microbial Communities in Sediment from Zostera marina Patches, but Not the Z. marina Leaf or Root Microbiomes, Vary in Relation to Distance from Patch Edge. PeerJ 2017, 5, e3246. [CrossRef]

90. Fahimipour, A.K.; Kardish, M.R.; Lang, J.M.; Green, J.L.; Eisen, J.A.; Stachowicz, J.J. Global-Scale Structure of the Eelgrass Microbiome. Appl. Environ. Microbiol. 2017, 83. [CrossRef]

91. Jiang, Z.-F.; Xia, F.; Johnson, K.W.; Bartom, E.; Tuteja, J.H.; Stevens, R.; Grossman, R.L.; Brumin, M.; White, K.P.; Ghanim, M. Genome Sequences of the Primary Endosymbiont "Candidatus Portiera Aleyrodidarum" in the Whitefly Bemisia Tabaci B and Q Biotypes. J. Bacteriol. 2012, 194, 6678-6679. [CrossRef]

92. Campbell, A.M.; Fleisher, J.; Sinigalliano, C.; White, J.R.; Lopez, J.V. Dynamics of Marine Bacterial Community Diversity of the Coastal Waters of the Reefs, Inlets, and Wastewater Outfalls of Southeast Florida. Microbiologyopen 2015, 4, 390-408. [CrossRef]

93. Yu, S.-X.; Pang, Y.-L.; Wang, Y.-C.; Li, J.-L.; Qin, S. Distribution of Bacterial Communities along the Spatial and Environmental Gradients from Bohai Sea to Northern Yellow Sea. Peer] 2018, 6, e4272. [CrossRef]

94. Lee, J.; Lim, J.-H.; Park, J.; Youn, S.-H.; Oh, H.-J.; Kim, J.-H.; Kim, M.K.; Cho, H.; Yoon, J.-E.; Kim, S.; et al. First Investigation of Microbial Community Composition in the Bridge (Gadeok Channel) between the Jinhae-Masan Bay and the South Sea of Korea. Ocean Sci. J. 2018, 53, 251-260. [CrossRef]

95. Sassoubre, L.M.; Yamahara, K.M.; Boehm, A.B. Temporal Stability of the Microbial Community in Sewage-Polluted Seawater Exposed to Natural Sunlight Cycles and Marine Microbiota. Appl. Environ. Microbiol. 2015, 81, 2107-2116. [CrossRef]

96. Rina, R.Y.; Yehuda, B.; Lea, R.; Uri, G. The Gill Microbiota of Invasive and Indigenous Spondylus Oysters from the Mediterranean Sea and Northern Red Sea. Environ. Microbiol. Rep. 2015, 7, 860-867.

97. Garrity, G.M.; Bell, J.A.; Lilburn, T. Oceanospirillales ord. nov. BT. In Bergey's Manual ${ }^{\circledR}$ of Systematic Bacteriology. Volume Two: The Proteobacteria Part B The Gammaproteobacteria; Brenner, D.J., Krieg, N.R., Staley, J.T., Garrity, G.M., Boone, D.R., De Vos, P., Goodfellow, M., Rainey, F.A., Schleifer, K.-H., Eds.; Springer: Boston, MA, USA, 2005; pp. 270-323.

98. Marba, N.; Duarte, C.; Alexandre, A.; Cabaço, S. How Do Seagrasses Grow and Spread? In European Seagrasses: An Introduction to Monitoring and Management; Borum, J., Duarte, C.M., Krause-Jensen, D., Greve, T.M., Eds.; EU Project Monitoring and Managing of European Seagrasses (M\&MS), 2004. Available online: http:/ / www.seagrasses.org/ (accessed on 15 October 2018).

99. Raja, S.; Thangaradjou, T.; Sivakumar, K.; Kannan, L. Rhizobacterial Population Density and Nitrogen Fixation in Seagrass Community of Gulf of Mannar, India. J. Environ. Biol. 2012, 33, 1033-1037.

100. Kaldy, J.; Eldridge, P.M.; Cifuentes, L.; Brian Jones, W. Utilization of DOC from Seagrass Rhizomes by Sediment Bacteria: 13C-Tracer Experiments and Modeling. MEPS 2006, 317, 41-55. [CrossRef]

101. Wahbeh, M.I.; Mahasneh, A.M. Heterotrophic Bacteria Attached to Leaves, Rhizomes and Roots of Three Seagrass Species from Aqaba (Jordan). Aquat. Bot. 1984, 20, 87-96. [CrossRef]

102. Lehnen, N.; Marchant, H.K.; Schwedt, A.; Milucka, J.; Lott, C.; Weber, M.; Dekaezemacker, J.; Seah, B.K.B.; Hach, P.F.; Mohr, W.; et al. High Rates of Microbial Dinitrogen Fixation and Sulfate Reduction Associated with the Mediterranean Seagrass Posidonia Oceanica. Syst. Appl. Microbiol. 2016, 39, 476-483. [CrossRef]

103. Capone, D.G.; Budin, J.M. Nitrogen Fixation Associated with Rinsed Roots and Rhizomes of the Eelgrass Zostera marina. Plant Physiol. 1982, 70, 1601-1604. [CrossRef] 
104. Pereg, L.L.; Lipkin, Y.; Sar, N. Different Niches of the Halophila Stipulacea Seagrass Bed Harbor Distinct Populations of Nitrogen Fixing Bacteria. Mar. Biol. 1994, 119, 327-333. [CrossRef]

105. Santos-Medellín, C.; Edwards, J.; Liechty, Z.; Nguyen, B.; Sundaresan, V. Drought Stress Results in a Compartment-Specific Restructuring of the Rice Root-Associated Microbiomes. MBio 2017, 8, e00764-17. [CrossRef]

106. Smith, R.D.; Pregnall, A.M.; Alberte, R.S. Effects of Anaerobiosis on Root Metabolism of Zostera marina (Eelgrass): Implications for Survival in Reducing Sediments. Mar. Biol. 1988, 98, 131-141. [CrossRef]

107. Kuever, J.; Rainy, F.A.; Widdel, F. Genus II Desulfocapsa. In Bergey's Manual of Systematic Bacteriology: The Proteobacteria, PartC (The Alpha-, Beta-, Delta-, and Epsilonproteobacteria); Staley, J.T., Brenner, D.J., Krieg, N.R., Eds.; Springer Science \& Business Media: New York, NY, USA, 2005; pp. 992-994.

108. Dörries, M.; Wöhlbrand, L.; Kube, M.; Reinhardt, R.; Rabus, R. Genome and Catabolic Subproteomes of the Marine, Nutritionally Versatile, Sulfate-Reducing Bacterium Desulfococcus Multivorans DSM 2059. BMC Genom. 2016, 17, 918. [CrossRef]

109. Rizzo, L.; Fraschetti, S.; Alifano, P.; Tredici, M.S.; Stabili, L. Association of Vibrio Community with the Atlantic Mediterranean Invasive Alga Caulerpa Cylindracea. J. Exp. Mar. Biol. Ecol. 2016, 475, 129-136. [CrossRef]

110. Nilsson, E. Methods to Measure Biomass and Production of Bacteria and Photosynthetic Microbiota and Their Application on Illuminated Lake Sediments. A Literature Study (SKB-R-01-23); Swedish Nuclear Fuel and Waste Management Co.: Stockholm, Sweden, 2001.

(C) 2018 by the authors. Licensee MDPI, Basel, Switzerland. This article is an open access article distributed under the terms and conditions of the Creative Commons Attribution (CC BY) license (http://creativecommons.org/licenses/by/4.0/). 